\title{
Different aspects of pork curing in Corsica
}

M. MOLENAT, F. CASABIANCA *, B. JACQUET **, P. POTERRE**

I.N.R.A., Station de Génétique quantitative et appliquée, 78350 Jouy-en-Josas

*I.N.R.A., Laboratoire de Recherches sur le Développement de l'élevage en Corse, 20250 Corte

:* I.N.R.A., Centre technique de la Salaison, de la Charcuterie

et des Conserves de Viande, Laboratoire expérimental, 78350 Jouy-en-Josas France

A total of 40 animals of three different genotypes (Large White, Corsican, Crossbreds) were managed according to three production systems : intensive, semi-extensive, extensive. This paper reports the overall results obtained until commercialization of the products.

Concerning growth, the following should be emphasized : the weight of an animal at a given time results from a succession of periods of growth, stagnation and mobilization of body reserves, and a few and relatively simple interventions allow in some cases to improve the growth curve, i.e. to gain one year.

The composition of the carcasses was highly variable, but a $70 \mathrm{~kg}$ carcass supplied on an average $39 \mathrm{~kg}(56 \mathrm{p}$. 100) of fresh products (lonzu, coppa, hams, sausage mixture, ficatellu mixture). During the drying process, losses varied from 27 p. 100 (ham) to 47 p. 100 (sausage). Thus, a $70 \mathrm{~kg}$ carcass supplied $26.5 \mathrm{~kg}$ of dry products (about 40 p. 100 of the fresh carcass weight).

According to the analyses of the fresh meat (bacteriostatic capacity, p. 100 free water, fat rancidity index, reducing capacity), the quality of the fresh products was excellent. However, it was observed that poor management conditions reduced the meat quality.

Sausages were examined during drying ( $\mathrm{pH}$, water activity, amount of total volatile basic nitrogen, mesophilic flora, pseudomonas, anaerobic germs, sulphito-reductors). Bacterial counts were very low as well in fresh meat as in products subjected to maturation (which might lead to a contamination). Despite this, we did not notice any losses of sausages due to contaminations. It may be asked whether contaminations in meat from relatively old animals are different from those occurring in meat from young animals.

Products intended for commercialization were subjected to three taster panels. As the results were contradictory no definitive conclusions could be drawn.

\section{Organoleptic qualities of meat from crossbred Pietrain $\times$ Chinese pigs}

\author{
C. TOURAille, G. MONIN, C. LEGAULT * \\ I.N.R.A., Station de Recherches sur la Viande, Theix, 03122 Ceyrat \\ * I.N.R.A., Station de Génétique quantitative et appliquée, 78350 Jouy-en-Josas \\ France
}

The main organoleptic characteristics of meat from Pietrain pigs and Pietrain $\times$ Chinese crossbred pigs (Jiaxing and Meishan) were compared by a taster panel. Two roasts (Longissimus dorsi) were sampled from the loin of 12 animals (6 Pietrain and 6 crossbreds, 6 castrated males and 6 females). Results showed that meat from Chinese crossbred animals was more tender and juicy and had a stronger flavour than that of the Pietrain pigs. Means of scores (ranging from 0 to 10) were following :

- for tenderness, 5.6 (crossbreds) and 4.1 (Pietrain),

- for juiciness, 4.6 (crossbreds) and 3.4 (Pietrain),

- for flavour, 5.2 (crossbreds) and 4.5 (Pietrain).

Differences were highly significant for the three characteristics. 